\title{
Dietary oxidized oil influences the levels of type 2 T-helper cell-related antibody and inflammatory mediators in mice
}

\author{
Bi-Fong Lin ${ }^{1}$, Chia-Chun Lai ${ }^{1}$, Kai-Wei Lin ${ }^{1}$, and Bor-Luen Chiang ${ }^{2 *}$ \\ ${ }^{1}$ Laboratory of Nutritional Chemistry, Department of Agricultural Chemistry, College of Agriculture, National Taiwan \\ University, Taipei, Taiwan 10764, Republic of China \\ ${ }^{2}$ Graduate Institute of Clinical Medicine, College of Medicine, National Taiwan University, Taipei, Taiwan 100, Republic of
} China

(Received 22 September 2000 - Revised 13 June 2000 - Accepted 17 July 2000)

\begin{abstract}
The aim of this present study was to investigate the effect of amount and degree of oxidation of dietary oil on type $2 \mathrm{~T}$-helper cell (TH)-related immune responses. Four groups of BALB/c mice were fed either $50 \mathrm{~g}$ soyabean oil/ $/ \mathrm{kg}(50-\mathrm{S}), 50 \mathrm{~g}$ oxidized oil $/ \mathrm{kg}(50-\mathrm{O}), 150 \mathrm{~g}$ soyabean oil $/ \mathrm{kg}$ $(150-\mathrm{S})$ or $150 \mathrm{~g}$ oxidized oil $/ \mathrm{kg}(150-\mathrm{O})$. After 14 weeks consuming the experimental diets, the mice were immunized with ovalbumin (OVA) plus $\mathrm{Al}$ and antigen-specific immunoglobulin $(\mathrm{Ig}) \mathrm{E}, \mathrm{IgG}_{1}$ and $\mathrm{IgG}_{2 \mathrm{a}}$, inflammatory mediators such as prostaglandin (PG) $\mathrm{E}_{2}$ and leukotriene (LT) $B_{4}$ were determined. Higher hepatic microsomal cytochrome $\mathrm{P} 450$ was noted in mice fed $150 \mathrm{~g}$ oxidized oil $/ \mathrm{kg}$ compared with those of other groups. OVA-specific $\operatorname{IgG}_{1}$ and $\operatorname{IgE}$ were higher in mice fed $150 \mathrm{~g}$ oxidized oil $/ \mathrm{kg}$ compared with those of the other groups. The data suggested the interleukin (IL)-4: interferon (IFN)- $\gamma$ ratio was higher in mice fed $50 \mathrm{~g}$ dietary oxidized oil $/ \mathrm{kg}$ compared with that of the $50-\mathrm{S}$ group. The IL-5:IFN- $\gamma$ ratios were higher in the $150-\mathrm{S}$ and $150-\mathrm{O}$ groups than in the $50-\mathrm{S}$ and $50-\mathrm{O}$ groups. $\mathrm{PGE}_{2}$ and $\mathrm{LTB}_{4}$ produced by macrophages stimulated by lipopolysaccharide were highest in mice in the $150 \mathrm{~g}$ oxidized oil $/ \mathrm{kg}$ group. The data suggested that an increased intake of oxidized oil might exert an unfavourable effect on the $\mathrm{TH}_{2}$ response involved in allergic disease.
\end{abstract}

Oxidized oil: Immunoglobulin E: Asthma: Prostaglandin $E_{2}$ : Leukotrienes

It has been well documented that environmental factors such as polluted air, tobacco, diet and infectious diseases play a critical role in the recently increasing prevalence of allergic diseases (Kimber, 1998). Several studies have demonstrated that both the quantity and quality of fat intake may play an important role in increasing the prevalence and severity of allergic diseases (Black \& Sharpe, 1997; Hodge et al. 1998). Certain diets such as low-fat and fish-oilcontaining diets have been shown to modulate the disease course of asthma or chronic lung disease (Arm et al. 1988; Smit et al. 1999; Schwartz, 2000).

Although the mechanism explaining how dietary fat affects immune response is still not well defined, several studies have suggested the involvement of a malfunction of macrophages and alterations in the production of proinflammatory mediators such as arachidonic acid, leukotrienes (LT), platelet activating factor, interleukin (IL)-1 and tumour necrosis factor- $\alpha$ (Sperling et al. 1987; Endres et al. 1989). In particular, the amount and composition of polyunsaturated fatty acids have been found to affect the synthesis of immune mediators such as prostaglandins (PG) and LT (Caughey et al. 1996). Much attention has been focused on polyunsaturated fatty acids of the $n-3$ class such as docosahexaenoic acid and eicosapentanoic acid, which are suggested to decrease the formation of these inflammatory mediators, including $\mathrm{LTB}_{4}, \mathrm{LTC}_{4}, \mathrm{LTD}_{4}$ and $\mathrm{LTE}_{4}$. Very few papers concerning the effect of oxidized oil by frying on immune responses have been reported; however, dietary oxidized oil may actually play an important role in health and in diseases (Lin et al. 1997). Dietary oxidized oil influences the hepatic and serum levels of triacylglycerol, cholesterol and hepatic cytochrome P450 (Lai \& Lin, 1997; Lai et al. 1997). In addition, the degree of lipid oxidation can affect lymphoid organs and influence immune responses in normal mice (Oarada et al. 1989, 1991). It is believed that an increased dietary content of oxidized oil

\footnotetext{
Abbreviations: IFN, interferon; Ig, immunoglobulin; IL, interleukin; LT, leukotriene; OVA, ovalbumin; PG, prostaglandin; TH, T-helper cell.

* Corresponding author: Dr Bor-Luen Chiang, fax +2 2397 2031, email gicmbor@ha.mc.ntu.edu.tw
} 
might result in the aggravation of such immune diseases as autoimmune diseases, allergic diseases and tumours (Lin et al. 1996).

No studies concerning the effect of oxidized oil on the immune response in animal models of allergic disease have been documented. This present study further investigated the effect of oxidized oil on serum levels of antigenspecific antibody, cytokine production pattern and inflammatory mediators.

\section{Materials and methods}

\section{Preparation of oxidized oil and diets}

The oxidized oil was prepared as follows: $5.5 \mathrm{~kg}$ soyabean oil (President Co., Tainan, Taiwan) was poured into a castiron wok $(40 \mathrm{~cm}$ internal diameter, $10 \mathrm{~cm}$ central depth, 6.5 litre capacity) and heated on a gas stove which was adjusted to maintain the oil temperature at $205 \pm 5^{\circ} \mathrm{C}$. Wheat-flour dough sheets $(12 \times 4.5 \times 0.15 \mathrm{~cm}$, about $11 \mathrm{~g}$ in weight) were fried in the oil, one at a time. The wheatflour dough was made by mixing together $(\mathrm{g})$; high-gluten wheat flour 1500, table sugar 200, baking powder 5, water 600. The frying proceeded for $6 \mathrm{~h} / \mathrm{d}$ and was repeated successively for $4 \mathrm{~d}$ according to the previously reported procedures (Huang et al. 1988; Lin et al. 1996). The resultant oxidized oil as well as the unfried fresh soyabean oil was stored at $-20^{\circ} \mathrm{C}$ for the preparation of test diets. The fatty acid compositions of the fresh soyabean oil and the oxidized oil were measured according to the method described by Lee et al. (1990). The degree of oxidation was evaluated as acid value, absorbance at $233 \mathrm{~nm}$, total polar compounds, and the non-urea-adductable fractions (Sallee, 1971). The quality of the soyabean oil declined after $24 \mathrm{~h}$ frying process (Table 1). The composition of experimental diets is summarized in Table 2. The casein content was increased in the $150 \mathrm{~g}$ oil $/ \mathrm{kg}$ diets to provide the same \% energy from protein as the $50 \mathrm{~g}$ oil $/ \mathrm{kg}$ diet.

\section{Animals and immunization}

Female BALB/c mice between 6 and 8 weeks of age were purchased from the Animal Centre of the College of Medicine at National Taiwan University. The animal room had a $12 \mathrm{~h}$ light-dark cycle and a constant temperature $\left(25 \pm 2{ }^{\circ} \mathrm{C}\right)$ and humidity. The mice were housed individually in stainless-steel wire cages and fed on a non-purified diet (Lab Rodent Chow; Ralson Purina, St Louis, MO, USA) before being fed on the experimental diets. Animal care and handling conformed to the National Institutes of Health's Guide for the Care and Use of Laboratory Animals (National Research Council, 1985). Each mouse was fed on the experimental diet starting from 13-weeksold. The four diets used contained either $50 \mathrm{~g}$ soyabean oil/ $\mathrm{kg}$ (50-S), $50 \mathrm{~g}$ oxidized soyabean oil/kg (50-O), $150 \mathrm{~g}$ soyabean oil/kg (150-S) or $150 \mathrm{~g}$ oxidized soyabean oil $/ \mathrm{kg}$ (150-O). The mice were given free access to the test diets throughout the experiment. The mice were weighed twice per week, and food consumption was measured every 2-3 d. Each group included eight mice. In addition, eight mice per
Table 1 . The fatty acid composition ( $\mathrm{g} / 100 \mathrm{~g}$ total fatty acids) and the degree of oxidation of fresh soyabean oil and oxidized frying soyabean oil $^{\star}$

\begin{tabular}{lcc}
\hline & $\begin{array}{c}\text { Fresh soyabean } \\
\text { oil }\end{array}$ & $\begin{array}{c}\text { Oxidized soyabean } \\
\text { oil }\end{array}$ \\
\hline Fatty acid & 11.4 & 9.3 \\
16:0 & 3.9 & 3.2 \\
$18: 0$ & 21.0 & 16.9 \\
$18: 1$ & $52 \cdot 3$ & 24.5 \\
$18: 2$ & 6.9 & 1.8 \\
$18: 3$ & 5.4 & 44.2 \\
Unidentified & 0.22 & $2 \cdot 23$ \\
Acid value (mg KOH/g) & 479 & 4912 \\
UV233 nm (absorbance/g) $\dagger$ & 6.27 & 69.1 \\
Total polar compound (\%) & 1.35 & 15.0 \\
NUAF (\%) & & \\
\hline
\end{tabular}

NUAF, non-urea-adductable fraction.

* For details of procedures see p. 912.

† UV233 is the absorbance of light of wavelength $233 \mathrm{~nm}$ after proper dilution with $n$-hexane, expressed as absorbance (optical density)/g oil.

group were killed for lipid analysis, cytokine assay and proliferative study.

After 14 weeks of consuming the test diets (27-weeksold), four groups of BALB/c mice were immunized by an intraperitoneal injection of $0 \cdot 1 \mathrm{ml}$ PBS solution containing ovalbumin (OVA, $2 \mu \mathrm{g}$ ) with $\mathrm{AlOH}$ as the adjuvant. The mice were immunized again, 2 weeks later, with $6 \mu \mathrm{g}$ OVA plus the same adjuvant (Chuang et al. 1996). Blood was obtained at days 0,14 and 28 from the retro-orbital venous plexus and centrifuged at $12000 \mathrm{~g}$ for $10 \mathrm{~min}$. Serum was collected and stored at $-20^{\circ} \mathrm{C}$ before further assay.

\section{Determination of serum anti-ovalbumin antibody levels}

Serum anti-OVA IgE, $\operatorname{IgG}_{1}$ and $\mathrm{IgG}_{2 \mathrm{a}}$ antibody titers were measured by ELISA. Briefly, ninety-six-well flat-bottomed microtiter plates (Costar, Cambridge, MA, USA) were coated with $10 \mu \mathrm{g} \mathrm{OVA} / \mathrm{ml} \mathrm{NaHCO}_{3}$ buffer, $\mathrm{pH}$ 9.6. After overnight incubation at $4{ }^{\circ} \mathrm{C}$, the plates were washed three

Table 2. Composition of experimental diets ( $\mathrm{g} / \mathrm{kg}$ diet)

\begin{tabular}{lrrrr}
\hline Ingredient $^{*}$ & $50-\mathrm{S} \dagger$ & $50-\mathrm{O} \dagger$ & $150-\mathrm{S} \dagger$ & $150-\mathrm{O} \dagger$ \\
\hline Fresh soyabean oil & 50 & - & 150 & - \\
Fried soyabean oil & - & 50 & - & 150 \\
Casein & 200 & 200 & 224 & 224 \\
Methionine & 3 & 3 & 3 & 3 \\
Cornstarch & 325 & 325 & 258 & 258 \\
Sucrose & 325 & 325 & 258 & 258 \\
Cellulose & 50 & 50 & 55 & 55 \\
AlN-76 vitamin mix & 10 & 10 & 11 & 11 \\
AlN-76 mineral mix & 35 & 35 & 39 & 39 \\
Choline & 2 & 2 & 2 & 2 \\
Energy (kJ/kg) & 16170 & 16170 & 18102 & 18102 \\
\% Energy from protein & 20.8 & $20 \cdot 8$ & 20.8 & 20.8 \\
\% Energy from fat & 11.7 & 11.7 & 31.3 & 31.3 \\
\hline
\end{tabular}

* Ingredient sources: casein, methionine and choline, Sigma Chemical (St Louis, MO, USA); sucrose, Taiwan Sugar Company (Taipei, Taiwan); cornstarch, Roquatte (Paris, France); $\alpha$-cellulose, ARBOCEL ${ }^{\circledR}$, type BE $600 / 300$, J. Bettenmaier \& Söhne (Ellwangen-Holzmühle, Germany).

† 50-S, $50 \mathrm{~g}$ fresh soyabean oil/kg diet; $50-\mathrm{O}: 50 \mathrm{~g}$ oxidised soyabean oil $/ \mathrm{kg}$ diet; $150-\mathrm{S} ; 150 \mathrm{~g}$ fresh soyabean oil/kg diet; 150-O; $150 \mathrm{~g}$ oxidised oil/kg diet. For details of oxidation procedure, see p. 912.

$\ddagger$ American Institute of Nutrition (1977). 
times with PBS buffer and blocked with adult bovine serum $(50 \mathrm{~g} / \mathrm{l})$ for $2 \mathrm{~h}$ at room temperature. After washes with PBS buffer, serum samples were diluted 1:10 in buffer(10 $\mathrm{g}$ bovine serum albumin/l PBS) for overnight incubation at $4^{\circ} \mathrm{C}$. Plates were then washed with PBS buffer containing $0.5 \mathrm{ml}$ Tween 20/1. Either $0.1 \mathrm{ml}$ biotinconjugated anti-mouse $\mathrm{IgG}_{1}, \mathrm{IgG}_{2 \mathrm{a}}$ or $\mathrm{IgE}$, diluted in buffer (10 $\mathrm{g}$ bovine serum albumin/l PBS), was added. After $1 \mathrm{~h}$, streptavidin-conjugated peroxidase was added. After a further $2 \mathrm{~h}$ the wells were washed with buffer (PBS buffer containing $0.5 \mathrm{ml}$ Tween 20/1), $0.1 \mathrm{ml}$ enzyme substrate solution (5.5 mg 2,2'-azino-bis-3-ethyl-benzthiazoline-6sulfonic acid (Sigma Chemical Co., St Louis, MO, USA) in $10 \mathrm{ml}$ phosphate-citric buffer containing $0.01 \mathrm{ml} \mathrm{H}_{2} \mathrm{O}_{2} /$ 1) per well was added. After $30 \mathrm{~min}$ incubation at room temperature, $50 \mu \mathrm{l} \mathrm{SDS} \mathrm{(100} \mathrm{g/l)} \mathrm{were} \mathrm{added} \mathrm{to} \mathrm{each} \mathrm{well}$ to stop the reaction. Absorbance was determined at $415 \mathrm{~nm}$ (Microplate; Bio-Tek Instrument, Inc. Winooski, VT, USA). The antibody levels of samples were compared with the standard. The standard serum was a pool of serum collected from OVA-immunized mice with strong responses (usually optical density $>1$ ). The concentration of standard serum was arbitrarily assigned 1 ELISA unit.

\section{Liver cytochrome P450 activity}

Livers were homogenized and centrifuged at $12000 \mathrm{~g}$ for $20 \mathrm{~min}$ at $4^{\circ} \mathrm{C}$. The supernatants were then further ultracentrifuged (105 $000 \mathrm{~g}$; XL90, Beckman, Los Angeles, CA, USA) for $1 \mathrm{~h}$ and microsomes were isolated. The microsomal suspension was dissolved in buffer for further analysis. Cytochrome P450 content was determined by the dithionite-CO binding difference spectrum at $450 \mathrm{~nm}$ (Omura \& Sato, 1964).

\section{Ovalbumin-specific proliferative assays}

To assay antigen-proliferative response further, spleen cells from OVA-immunized mice were plated in ninety-six-well round-bottomed plates with a concentration of $1 \times$ $10^{6}$ cells $/ \mathrm{ml}$ in RPMI 1640 medium supplemented with $20 \mathrm{ml}$ defined serum replacement/l $\left(\mathrm{TCM}^{\mathrm{TM}}\right.$; Celox Co., Hopkins, MN, USA), 4 mM/L-glutamine, 25 mM-HEPES, $5 \times 10^{-5}$ M2-mercaptoethanol, $100 \mathrm{U}$ penicillin $/ \mathrm{ml}$, $100 \mu \mathrm{g}$ streptomycin $/ \mathrm{ml}$ and $0.25 \mathrm{mg}$ amphotericin $/ \mathrm{ml}$ in the absence or the presence of different concentrations of OVA (10 or $20 \mu \mathrm{g} / \mathrm{ml})$ or anti-CD3 antibody $(1 \mu \mathrm{g} / \mathrm{ml})$. The cells were incubated at $37^{\circ} \mathrm{C}$ with $5 \% \mathrm{CO}_{2}$ for $72 \mathrm{~h}$. At $16 \mathrm{~h}$ before harvest, $37 \mathrm{kBq}\left[{ }^{3} \mathrm{H}\right]$ thymidine was added to each well. The cells were harvested and radioactivity was measured with a $\beta$-counter (Beckman LS $5000 \mathrm{CE}$; Beckman). The data were expressed as the stimulation index: $\left(\right.$ sample $_{\mathrm{cpm}}-$ blank $\left._{\mathrm{cpm}}\right) /\left(\right.$ control $_{\mathrm{cpm}}-$ blank $\left._{\mathrm{cpm}}\right)$, where cpm is the counts/min.

\section{Cytokine assay}

Spleen cells, at a concentration of $5 \times 10^{6}$ cells $/ \mathrm{ml}$, were cultured with the medium described earlier in the absence or presence of OVA $(20 \mu \mathrm{g} / \mathrm{ml})$ for $48 \mathrm{~h}$. Cytokine secretions by single cell suspensions of spleen cells were measured by sandwich-ELISA. Briefly, ninety-six-well flat-bottomed microtiter plates were coated with anticytokine antibody diluted in $\mathrm{NaHCO}_{3}$ buffer, $\mathrm{pH}$ 9.6. After overnight incubation at $4^{\circ} \mathrm{C}$, plates were washed three times and blocked with bovine serum albumin $(30 \mathrm{~g} / \mathrm{l})$ at $37^{\circ} \mathrm{C}$. After three washes with PBS containing $0.5 \mathrm{ml}$ Tween $20 / 1$, $0 \cdot 1 \mathrm{ml}$ sample was added for $2 \mathrm{~h}$ at $37^{\circ} \mathrm{C}$. Plates were then washed with PBS buffer containing $0.5 \mathrm{ml}$ Tween 20/1 and biotin-conjugated anti-cytokine antibody diluted in buffer (10 g bovine serum albumin/l PBS) was added and incubated at $37^{\circ} \mathrm{C}$ for $1 \mathrm{~h}$. After washes, streptavidinconjugated peroxidase was added for an additional $1 \mathrm{~h}$. After the wells were washed, $0 \cdot 1 \mathrm{ml}$ enzyme substrate of 2,2'-azino-bis-3-ethyl-benzthiazoline-6-sulfonic acid solution was added to each well and the plate was left in a dark room for about $30 \mathrm{~min}$. Plates were read in a microplate autoreader at $415 \mathrm{~nm}$. The sensitivity of sandwich-ELISA used in our experiment is $15 \mathrm{pg} / \mathrm{ml}$ for IL-4, and $20 \mathrm{pg} / \mathrm{ml}$ for IL-5 and interferon (IFN)- $\gamma$.

\section{Isolation and stimulation of peritoneal exudate cells}

Peritoneal exudate cells were isolated by peritoneal lavage and washed three times with Hanks' solution before use. Peritoneal exudate cells with a concentration of $1.5 \times$ $10^{6}$ cells $/ \mathrm{ml}$ were set up in twenty-four-well plates in RPMI 1640 medium described earlier in the absence or presence of $5 \mu \mathrm{g}$ lipopolysaccharide/ml and incubated for $24 \mathrm{~h}$. The supernatant fraction was collected and used for determination of $\mathrm{PGE}_{2}$ and $\mathrm{LTB}_{4}$ productions. $\mathrm{PGE}_{2}$ and $\mathrm{LTB}_{4}$ were determined with an enzyme-linked immunoassay kit (Cayman Chemical Co., Ann Arbor, MI, USA).

\section{Statistical analysis}

The significance of difference among four groups was analysed statistically by one-way ANOVA and Duncan's log multiple range test or Scheffe's multiple range test of the Statistical Analysis System program system (SAS/ STAT version 6; SAS Institute Inc., Cary, NC, USA) throughout the study.

\section{Results \\ Feed intake and growth}

The feed intake and body weights of the mice are shown in Table 3. Although feed intake (g/d) was significantly lower in the $150 \mathrm{~g}$ fat $/ \mathrm{kg}$ groups, the daily energy and protein intakes were only significantly lower in $150-S$ group. The feed efficiency was significantly lower in the oxidized oil groups. Therefore, gain in body weight and final body weights were the lowest in 150-O group due to its lowest feed efficiency though there was no significant difference in initial body weight before the dietary treatment. The results suggested that the increased content of oxidized oil in the diet did decrease the feed efficiency of mice.

Mice fed oxidized oil (50-O, 150-O) had significantly higher relative liver weight compared with the mice fed fresh oil (Table 4). In contrast, mice of the 150-O group had significantly lower relative heart weight than those of the 
Table 3. The effect of experimental diets on body weight, gain in body weight, feed efficiency and total energy intake of ovalbumin-immunized BALB/c mice*

(Mean values with their standard errors for eight mice per dietary group)

\begin{tabular}{|c|c|c|c|c|c|c|c|c|}
\hline & \multicolumn{8}{|c|}{ Dietary fat } \\
\hline & \multicolumn{2}{|c|}{$50-S$} & \multicolumn{2}{|c|}{$50-0$} & \multicolumn{2}{|c|}{$150-S$} & \multicolumn{2}{|c|}{$150-O$} \\
\hline & Mean & SE & Mean & SE & Mean & SE & Mean & SE \\
\hline Initial body weight (g) & $23 \cdot 8$ & 0.6 & $24 \cdot 1$ & 0.6 & $23 \cdot 2$ & 0.4 & $23 \cdot 3$ & 0.5 \\
\hline Final body weight $(\mathrm{g})$ & $29 \cdot 8^{a}$ & 1.0 & $29 \cdot 2^{a}$ & 0.6 & $27 \cdot 2^{\mathrm{ab}}$ & 0.9 & $26 \cdot 1^{\mathrm{b}}$ & 0.8 \\
\hline Gain in body weight (g) & $7 \cdot 0^{\mathrm{a}}$ & 0.5 & $5 \cdot 2^{b}$ & 0.4 & $5 \cdot 1^{\mathrm{b}}$ & 0.6 & $3 \cdot 0^{\mathrm{C}}$ & 0.4 \\
\hline Intake $(\mathrm{g} / \mathrm{d})$ & $3.0^{\mathrm{a}}$ & 0.1 & $3.0^{\mathrm{a}}$ & 0.1 & $2 \cdot 4^{\mathrm{b}}$ & 0.2 & $2 \cdot 6^{\mathrm{b}}$ & 0.1 \\
\hline Feed efficiency (\%)† & $1.8^{\mathrm{a}}$ & 0.9 & $1 \cdot 4^{\mathrm{b}}$ & $1 \cdot 1$ & $1.7^{\mathrm{ab}}$ & 1.8 & $0.9^{c}$ & $1 \cdot 1$ \\
\hline Protein intake (g/d) & $0.60^{a b}$ & 0.02 & $0 \cdot 61^{\mathrm{a}}$ & 0.03 & $0.54^{\mathrm{b}}$ & 0.04 & $0.58^{a b}$ & 0.03 \\
\hline Energy intake (kJ/d) & $48 \cdot 1^{\mathrm{ab}}$ & 1.7 & $48 \cdot 5^{\mathrm{a}}$ & $2 \cdot 1$ & $43 \cdot 1^{\mathrm{b}}$ & 2.9 & $46 \cdot 4^{\mathrm{ab}}$ & $2 \cdot 1$ \\
\hline
\end{tabular}

a,b,c,d Mean values within a row with unlike superscript letters were significantly different ( $P<0.05$; one way ANOVA and Scheffe's multiple range test).

* Mice were fed for 18 weeks on a diet containing either $50 \mathrm{~g}$ soyabean oil/kg (50-S), $50 \mathrm{~g}$ oxidized soyabean oil/kg (50-O), 150 g soyabean oil/kg (150-S), or oxidized soyabean oil $/ \mathrm{kg}(150-\mathrm{O})$. For details of diets and procedures, see p. 912 and Tables 1 and 2.

$\dagger$ Feed efficiency $(\%)=($ gain in body weight $(\mathrm{g}) /$ total intake $(\mathrm{g})) \times 100$

$50 \mathrm{~g}$ fat $/ \mathrm{kg} 50-\mathrm{S}$ and $50-\mathrm{O}$ groups, and lower relative spleen weights than those of the fresh oil 50-S and 150-S groups. Mice of the 150-O group had a significantly higher hepatic thiobarbituric acid-reactive substance value (nmol/g organ) than that of the other groups (50-S, 0.97 (SE 0.11); 50-O, 0.85 (SE 0.10); 150-S, 1.28 (SE 0.12); 150-O, 1.73 (SE $0 \cdot 28)$ ). Although the thiobarbituric acid-reactive substance value of spleen was not determined in this study, our previous studies suggest no significant difference between mice fed the fresh oil or oxidized oil diets (Liu \& Huang 1995; Lin et al. 1997).

It has been well documented that hepatic cytochrome P450 contents significantly increase in rats fed oxidized oil compared with those of rats fed fresh oil (Huang et al. 1988). Thus, cytochrome $\mathrm{P} 450$ is a direct indicator of the dietary effect of oxidized oil. As shown in Table 4, hepatic cytochrome P450 content significantly increased in OVAimmunized BALB/c mice of 150-O group. The effect of oil quantity and quality on cytochrome P450 content was more obvious when data were expressed per g body weight.

\section{Serum anti-ovalbumin antibodies level}

Immunoglobulin (Ig)E anti-OVA antibody tended to be higher in mice of 150-O group than those of the other groups $(P=0.052 v .50-\mathrm{S}$ group, $P=0.084 v .50$-O group and $P=0.057 v$. 150-S group by non-paired Student's $t$ test) (Table 5). Furthermore, the $\mathrm{IgG}_{1}$ anti-OVA antibody level of mice fed $150 \mathrm{~g}$ oxidized oil $/ \mathrm{kg}$ was also significantly higher compared with mice fed 50 or $150 \mathrm{~g}$ fresh oil $/ \mathrm{kg}(P<0.05)$. Both $\mathrm{IgE}$ and $\mathrm{IgG}_{1}$ subclasses are affected by type 2 T-helper cell (TH)-related cytokines (Lee et al. 1999). In contrast, $\mathrm{TH}_{1}$-related $\mathrm{IgG}_{2 \mathrm{a}}$ anti-OVA antibody was significantly lower in mice fed high dietary oxidized oil when compared with mice fed fresh oil. All these data suggest that a large amount of dietary oxidized oil could increase $\mathrm{TH}_{2}$-related antigen-specific antibody production and subsequently cause more serious inflammatory response.

\section{Antigen-specific proliferative responses and cytokine secretion of spleen cells}

The results of $\mathrm{T}$ cell response to stimulation of OVA antigen are illustrated in Table 5. OVA antigen-specific proliferative response of spleen cells of mice fed dietary frying oil was lower, although statistically not significant, compared with those of the other groups. Furthermore, antiCD3 antibody stimulated proliferative response was significantly lower in mice fed $150 \mathrm{~g}$ oxidized oil $/ \mathrm{kg}$. The proliferative response tended to be lower in mice fed with higher amount of dietary oil (150-S and 150-O) compared

Table 4. Relative tissue weight ( $\mathrm{g} / \mathrm{kg}$ body weight) and liver microsomal cytochrome P450 contents of immunized BALB/c mice* (Mean values with their standard errors for eight mice per dietary group)

\begin{tabular}{|c|c|c|c|c|c|c|c|c|}
\hline & \multicolumn{2}{|c|}{$50-S$} & \multicolumn{2}{|c|}{$50-0$} & \multicolumn{2}{|c|}{$150-S$} & \multicolumn{2}{|c|}{$150-0$} \\
\hline & Mean & SE & Mean & SE & Mean & SE & Mean & SE \\
\hline \multicolumn{9}{|c|}{ Relative tissue weight ( $\mathrm{g} / \mathrm{kg}$ body weight) } \\
\hline Liver & $67 \cdot 0^{\mathrm{b}}$ & $4 \cdot 1$ & $89 \cdot 2^{\mathrm{a}}$ & $4 \cdot 3$ & $56 \cdot 2^{b}$ & $3 \cdot 1$ & $80 \cdot 8^{a}$ & $5 \cdot 1$ \\
\hline Spleen & $7 \cdot 6^{\mathrm{a}}$ & 0.4 & $6 \cdot 7^{\mathrm{ab}}$ & 0.6 & $8 \cdot 1^{a}$ & 0.4 & $5 \cdot 8^{\mathrm{b}}$ & 0.7 \\
\hline \multicolumn{9}{|c|}{ Hepatic microsomal cytochrome P450 } \\
\hline nmol per mg protein & $1 \cdot 2^{\mathrm{c}}$ & $0 \cdot 1$ & $1 \cdot 5^{\mathrm{bc}}$ & $0 \cdot 1$ & $1 \cdot 6^{\mathrm{b}}$ & $0 \cdot 1$ & $3 \cdot 0^{\mathrm{a}}$ & 0.2 \\
\hline nmol per $\mathrm{g}$ liver & $3.5^{\mathrm{b}}$ & 0.2 & $5 \cdot 0^{\mathrm{b}}$ & 0.3 & $5 \cdot 1^{\mathrm{b}}$ & 0.5 & $9 \cdot 4^{a}$ & 0.9 \\
\hline nmol per liver & $6.4^{\mathrm{b}}$ & 0.4 & $10 \cdot 5^{\mathrm{b}}$ & 0.8 & $7 \cdot 7^{\mathrm{b}}$ & 1.0 & $20 \cdot 1^{\mathrm{a}}$ & $3 \cdot 1$ \\
\hline $\mathrm{nmol}$ per kg body weight & $208^{\mathrm{C}}$ & 11 & $399^{\mathrm{b}}$ & 24 & $291^{c}$ & 36 & $841^{a}$ & 87 \\
\hline
\end{tabular}

a,b,c,d Mean values within a row with unlike superscript letters were significantly different $(P<0.05$; one way ANOVA and Scheffe's multiple range test).

* Mice were fed for 18 weeks on a diet containing either $50 \mathrm{~g}$ soyabean oil/kg (50-S), $50 \mathrm{~g}$ oxidized soyabean oil/kg (50-O), $150 \mathrm{~g}$ soyabean oil/kg (150-S), or $150 \mathrm{~g}$ oxidized soyabean oil/kg (150-O). For details of diets and procedures, see p. 912 and Tables 1 and 2. 
Table 5. Immunological variables of ovalbumin-immunized BALB/c mice fed on $50 \mathrm{~g}$ or $150 \mathrm{~g}$ fresh oil or oxidized oil/kg diet ${ }^{\star}$ (Mean values with their standard errors for eight mice per dietary group)

\begin{tabular}{|c|c|c|c|c|c|c|c|c|}
\hline & \multicolumn{2}{|c|}{$50-S$} & \multicolumn{2}{|c|}{$50-0$} & \multicolumn{2}{|c|}{$150-S$} & \multicolumn{2}{|c|}{$150-0$} \\
\hline & Mean & SE & Mean & SE & Mean & SE & Mean & SE \\
\hline \multicolumn{9}{|c|}{ OVA-specific immunoglobulin (ELISA units) } \\
\hline $\operatorname{lgG1}$ & $2 \cdot 1^{\mathrm{b}}$ & 0.3 & $2 \cdot 5^{\mathrm{ab}}$ & 0.4 & $2 \cdot 1^{\mathrm{b}}$ & 0.2 & $3 \cdot 1^{\mathrm{a}}$ & 0.4 \\
\hline $\lg G 2 a$ & $1.0^{\mathrm{a}}$ & $0 \cdot 1$ & $0.9^{a b}$ & 0.1 & $1 \cdot 1^{a}$ & $0 \cdot 1$ & $0.7^{\mathrm{b}}$ & $0 \cdot 1$ \\
\hline $\lg \mathrm{E}$ & 0.9 & 0.2 & 0.9 & 0.2 & 0.9 & 0.2 & 1.9 & 0.7 \\
\hline \multicolumn{9}{|c|}{ Proliferative response (stimulation index) $\dagger$} \\
\hline OVA $(10 \mu \mathrm{g} / \mathrm{ml})$ & $2 \cdot 0$ & 0.7 & $3 \cdot 7$ & 1.6 & $3 \cdot 0$ & 1.9 & $1 \cdot 1$ & 0.2 \\
\hline OVA $(20 \mu \mathrm{g} / \mathrm{ml})$ & $2 \cdot 6$ & 0.8 & $4 \cdot 2$ & 1.5 & $5 \cdot 0$ & $3 \cdot 4$ & $1 \cdot 2$ & 0.2 \\
\hline Anti-CD3 Ab $(1 \mu \mathrm{g} / \mathrm{ml})$ & $265 \cdot 8^{a}$ & $136 \cdot 3$ & $175 \cdot 7^{\mathrm{a}}$ & $106 \cdot 1$ & $104 \cdot 8^{a}$ & $35 \cdot 7$ & $48 \cdot 9^{b}$ & $19 \cdot 5$ \\
\hline \multicolumn{9}{|l|}{ Cytokine levels (ratio) } \\
\hline IL-4:IFN- $\gamma$ & $9 \cdot 1^{\mathrm{b}}$ & $0 \cdot 3$ & $12 \cdot 3^{a}$ & 0.5 & $10 \cdot 5^{\mathrm{ab}}$ & 0.7 & $9 \cdot 1^{\mathrm{b}}$ & 0.5 \\
\hline IL-5:IFN- $\gamma$ & $0.5^{\mathrm{a}}$ & 0.2 & $0.5^{a}$ & 0.1 & $1.7^{\mathrm{b}}$ & 0.5 & $1.4^{\mathrm{b}}$ & 0.2 \\
\hline \multicolumn{9}{|c|}{ Arachidonic acid metabolites $\left(\mathrm{pg} / 1 \times 10^{6}\right.$ cells $)$} \\
\hline $\mathrm{PGE}_{2}$ & $0.5^{\mathrm{b}}$ & 0.1 & $1.7^{\mathrm{ab}}$ & 0.5 & $2 \cdot 9^{\mathrm{ab}}$ & 0.9 & $3 \cdot 6^{\mathrm{a}}$ & $2 \cdot 0$ \\
\hline $\mathrm{LTB}_{4}$ & $49 \cdot 3^{a}$ & $21 \cdot 9$ & $77 \cdot 2^{a b}$ & $40 \cdot 6$ & $143 \cdot 7^{b}$ & $32 \cdot 7$ & $392.6^{\mathrm{C}}$ & $83 \cdot 9$ \\
\hline
\end{tabular}

OVA, ovalbumin; Ig, immunoglobulin; Ab, antibody; IL, interleukin; IFN, interferon; PG, prostaglandin; LT, leukotriene.

$\mathrm{a}, \mathrm{b}, \mathrm{c}, \mathrm{d}$ Mean values within a row with unlike superscript letters were significantly different $(P<0.05$; one way ANOVA and Scheffe's multiple range test).

* Mice were fed for 18 weeks on a diet containing either $50 \mathrm{~g}$ soyabean oil/kg (50-S), $50 \mathrm{~g}$ oxidized soyabean oil/kg (50-O), $150 \mathrm{~g}$ soyabean oil/kg (150-S), or $150 \mathrm{~g}$ oxidized soyabean oil/kg (150-O). For details of diets and procedures, see p. 912 and Tables 1 and 2

$\dagger$ Stimulation index $=\left(\right.$ sample $_{\mathrm{cpm}}-$ blank $\left._{\mathrm{cpm}}\right) /\left(\right.$ control $_{\mathrm{cpm}}-$ blank $\left._{\mathrm{cpm}}\right)$, where $\mathrm{cpm}$ is the counts per minute.

with those of 50-S and 50-O groups. In addition, the levels of cytokines produced by spleen cells stimulated with OVA antigen are presented in Table 5. The results were summarized as the IL-4:IFN- $\gamma$ and IL-5:IFN- $\gamma$ ratios. The data suggested the IL-4:IFN- $\gamma$ ratio was higher in mice fed $50 \mathrm{~g}$ dietary oxidized oil $/ \mathrm{kg}$ compared with that of $50-\mathrm{S}$ group. In contrast, there was no difference in the IL-4:IFN$\gamma$ ratio between the 150-S and 150-O groups. Furthermore, the IL-5:IFN- $\gamma$ ratio in mice of both $150-\mathrm{S}$ and $150-\mathrm{O}$ groups was higher than those of 50-S and 50-O groups.

\section{Prostaglandin $E_{2}$ and leukotriene $B_{4}$ level}

$\mathrm{PGE}_{2}$ and $\mathrm{LTB}_{4}$ produced by lipopolysaccharide-stimulated peritoneal exudate cells tended to be higher in mice fed with a high dietary frying oil (Table 5). $\mathrm{PGE}_{2}$ and $\mathrm{LTB}_{4}$ were not detectable when cells were cultured without lipopolysaccharide stimulation. $\mathrm{PGE}_{2}$ production of peritoneal exudate cells from mice in the 150-O group was also significantly higher than that in the 50-S group. Furthermore, $\mathrm{LTB}_{4}$ level in mice of $150-\mathrm{O}$ group was significantly higher compared with those of the other groups. These data suggested inflammatory mediators were higher in mice fed high dietary oxidized oil.

\section{Discussion}

Increasing prevalence of certain allergic diseases such as allergic rhinitis and bronchial asthma has been documented (Aberg et al. 1995). Among the environmental factors, air pollution and dietary habit change have been suggested to play the critical role (Barnes, 1994; Kimber, 1998). Changes in the amount and quality of dietary fat might have an important impact on immunological changes of these atopic diseases. Furthermore, fried food becomes an important fat source in the present-day industrialized dietary pattern, although the relative contribution is difficult to assess. Total energy contributed by dietary fat has been reported to have increased from $30 \%$ during the 1910 s to $36 \%$ during the 1980s in the US diet (Committee on Diet and Health Food and Nutrition Board, 1989). The $150 \mathrm{~g}$ fresh oil or oxidized oil $/ \mathrm{kg}$ diet used in the present study provides $31 \%$ total energy from fat.

It has been well documented that diet plays a role in asthma and immune function (Delafuente, 1991; Greene, 1999; Fogarty \& Britton, 2000). The data presented here are from one of the few studies to investigate the effect of oxidized oil on immunological changes in a murine model of asthma. Lower relative spleen weight was noted in OVA-immunized BALB/c mice fed on a diet containing $150 \mathrm{~g}$ oxidized oil $/ \mathrm{kg}$. In addition, lower mitogen-stimulated proliferative response of spleen cell was also noted in mice fed a high amount of oxidized oil, which has also been reported previously (Lin et al. 1997). These data suggested that high amount of oxidized oil intake results in impairment of spleen cells proliferative ability. It will be interesting to study the role of oxidative stress and related enzyme activity in the activation of immune cells further. In addition, it has been documented that $\mathrm{TH}_{1}$ and $\mathrm{TH}_{2}$ cells respond differently to distinct population of antigenpresenting cells (Weaver et al. 1988; Gajewski et al. 1991). The effect of antigen-presenting cells and accessory molecules on TH cells' functions are more pronounced on proliferative response rather than cytokine production ability. This may be the reason for the discrepancy between low proliferative response and active cytokine production in mice in the 150-O group. The data also showed higher IL-5:IFN- $\gamma$ ratio of cytokine profile produced by $\mathrm{T}$ cells of mice fed high amount of dietary fat. Cytokines such as IL-5 derived from $\mathrm{TH}_{2}$ cells were found to induce eosinophilia, which is critical in the late stage of inflammation of asthma (Marom et al. 1982). In addition, the IL-4:IFN- $\gamma$ ratio was higher in mice fed $50 \mathrm{~g}$ dietary oxidized oil $/ \mathrm{kg}$ compared with that of the 50-S group. Furthermore, OVA-specific 
$\operatorname{IgE}$ and $\mathrm{IgG}_{1}$ antibody production was not suppressed by dietary oxidized oil. Allergen-specific IgE and mast cells are the effector molecules and cells in triggering inflammatory responses in allergic diseases; however, the central theme of the pathogenic mechanisms involved in allergenic diseases is the role of allergen-specific $\mathrm{T}$ cells and related cytokines (Ishizaka, 1989; Chretien et al. 1990; Romagnanai, 1990). The result of the present study demonstrated increased $\mathrm{TH}_{2}$-related antigen-specific $\mathrm{IgE}$ and $\mathrm{IgG}_{1}$ antibody in mice fed high dietary oxidized oil. Since the IL$4: I F N-\gamma$ ratio was not increased in mice fed high dietary oxidized oil, the higher level of antigen-specific IgE might have resulted from the adjuvant effect of very high levels of $\mathrm{PGE}_{2}$ and $\mathrm{LTB}_{4}$ that have been suggested to enhance IgE production (Dugas et al. 1990; Yamaoka et al. 1994). All these data together suggested that both quantity and quality of dietary fat affected the production of antigenspecific $\operatorname{IgE}$ and $\operatorname{IgG}_{1}$ and inflammation-related cytokines.

Inflammatory mediators such as histamine, LT, PG, platelet-activating factor and chemokines have been documented to play a critical role in inflammation of late stage of asthma (Abraham et al. 1983; Russi et al. 1984). Among them, PG, LT and platelet-activating factor are the major metabolites derived from lipids (O'Byrne \& Manning, 1992). The present data demonstrated higher $\mathrm{PGE}_{2}$ and $\mathrm{LTB}_{4}$ levels in mice fed $150 \mathrm{~g}$ dietary oxidized oil $/ \mathrm{kg}$ compared with those of the other groups. $\mathrm{LTB}_{4}$, a potent chemotactic agent for the neutrophil, is important in evoking more serious inflammation during the late stage of asthma (Arm et al. 1988). The data also showed that $\mathrm{PGE}_{2}$ and $\mathrm{PGE}_{1}$ could increase intracellular cAMP level and negatively regulated $\mathrm{TH}_{1}$ development (Santoli \& Zurier, 1989; Betz \& Fox, 1991; Gold et al. 1994). Increased $\mathrm{PGE}_{2}$ and $\mathrm{LTB}_{4}$ levels might not only aggravate the inflammatory process, but also increase antigen-specific IgE production. Increased intake of dietary oxidized oil could result in increased prostaglandin production and subsequent higher $\mathrm{TH}_{2}$ activity. Higher cytochrome $\mathrm{P} 450$ content was noted in mice fed dietary oxidized oil, which is similar to the previous report (Huang et al. 1988). Although microsomal cytochrome $\mathrm{P} 450$ activity is more important for PG metabolism, certain enzymes such as PGH synthase implicated in the metabolism of arachidonic acid metabolism may also increase in mice fed oxidized oil (Raz et al. 1989). More studies are needed, however, as dietary oxidized oil may induce higher enzyme activity involved in the pathway of arachidonic acid metabolism and subsequently enhance the production of inflammatory mediators.

It is possible that unidentified fatty acids contained in the oxidized oil $(442 \mathrm{~g} / \mathrm{kg})$ might play a critical role in the detrimental effect of allergic response. More studies on the identification of the possible components are needed. The formation of volatile and non-volatile products in dietary oxidized oil has been reported (Chang et al. 1978). The major compounds formed during the frying process and left in oxidized oil are non-volatile. These non-volatile compounds can only be identified as non-urea-adductforming esters. The polymers formed during deep-fat frying were essentially dimers and trimers, which made the identification of these components relatively difficult.
However, it would be very informative if the active substance in oxidized oil responsible for the changes of inflammatory response could be identified in the future.

These present data demonstrated that increasing content of dietary oxidized oil in modern food could increase both IgE, the IL-4:IFN- $\gamma$ or IL-5:IFN- $\gamma$ ratio and inflammatory mediators such as $\mathrm{PGE}_{2}$ and $\mathrm{LTB}_{4}$, which are all hazardous for the disease severity of asthma.

\section{Acknowledgements}

The authors are grateful to Professor Min-Hsiung Lee for technical assistance in fatty acid composition analysis and Ms Wen-Shin Wang for assistance in hepatic lipid analysis. This study was supported by a grant from the National Science Council of the Republic of China; NSC 85-2331B-002-077.

\section{References}

Aberg N, Hesselmar B, Aberg B \& Eriksson B (1995) Increase of asthma, allergic rhinitis and eczema in Swedish schoolchildren between 1979 and 1991. Clinical and Experimental Allergy 25, 815-819.

Abraham WM, Delehunt JC, Yerger L \& Marchette B (1983) Characterization of a late phase pulmonary response after antigen challenge in allergic sheep. American Review of Respiratory Disease 128, 839-844.

Arm PJ, Horton CE, Mencia-Huerta JM, House F, Eiser NM, Clark TJ, Spur BW \& Lee TH (1988) Effect of dietary supplementation with fish oil lipids on mild asthma. Thorax $\mathbf{4 3}$, 84-92.

Barnes PJ (1994) Air pollution and asthma. Postgraduate Medical Journal 70, 319-325.

Betz M \& Fox BS (1991) Prostaglandin $E_{2}$ inhibits production of TH1 lymphokines but not of TH2 lymphokines. Journal of Immunology 146, 108-113.

Black PN \& Sharpe S (1997) Dietary fat and asthma: is there a connection? European Respiratory Journal 10, 6-12.

Caughey GE, Mantzioris E, Gibson RA, Cleland LG \& James MJ (1996) The effect on human tumor necrosis factor $\alpha$ and interleukin $1 \beta$ of diets enriched in $n-3$ fatty acids from vegetable oil or fish oil. American Journal of Clinical Nutrition 63, 116-122.

Chang SS, Peterson RJ \& Ho CT (1978) Chemical reactions involved in the deep-fat frying of foods. Journal of American Oil Chemists' Society 55, 718-727.

Chretien I, Pene J, Briere F, Malefijt RDW \& Rousset JED (1990) Regulation of human IgE synthesis. I. Human IgE synthesis in vitro is determined by the reciprocal antagonistic effects of interleukin-4 and interferon- $\gamma$. European Journal of Immunology 20, 243-251.

Chuang Y-H, Chiang B-L, Chou C-C \& Hsieh K-H (1996) Different kinds of antigen-presenting cells exert different effects on T-helper cells development. International Archives of Allergy and Immunology 111, 366-371.

Committee on Diet and Health Food and Nutrition Board (1989) Dietary intake and nutritional status: Trends and assessment. In Diet and Health, pp. 54-58 [AG Motulsky chairman]. Washington, DC: National Academy Press.

Delafuente JC (1991) Nutrients and immune responses. Rheumatic Disease Clinic North America 17, 203-212.

Dugas B, Paul-Eugene N, Cairns J, Gordoc J, Calenda A, MenciaHuerta J \& Braquet P (1990) Leukotriene $B_{4}$ potentiates the expression and release of $\mathrm{FCeRII/Cd} 3$ and proliferation and 
differentiation of human B lymphocytes induced by IL-4. Journal of Immunology 145, 3406-3411.

Endres S, Ghorbani RVE, Kelley K, Georgilis G, Lonnemann JWM, van der Meer JG, Cannon TS, Rogers MS, Weber PC, Schaffer EJ, Wolff SM \& Dinarello CA (1989) The effect of dietary supplementation with $n-3$ polyunsaturated fatty acids on the synthesis of interleukin- 1 and tumor necrosis factor by mononuclear cells. New England Journal of Medicine 320, $265-271$

Fogarty A \& Britton J (2000) Nutritional issues and asthma. Current Opinion in Pulmonary Medicine 6, 86-89.

Gajewski TF, Pinnas M, Wong T \& Fitch FW (1991) Murine Th1 and $\mathrm{Th} 2$ clones proliferate optimally in response to distinct antigen-presenting cell populations. Journal of Immunology 146, 1750-1758.

Gold KN, Weyand CM \& Goronzy JJ (1994) Modulation of helper $\mathrm{T}$ cell function by prostaglandins. Arthritis Rheumatism 37, 925-933.

Greene LS (1999) Asthma, oxidant stress, and diet. Nutrition 15, 899-907.

Hodge L, Salome CM, Hughes JM, Liu-Brennan D, Rimmer J, Allman M, Pang D, Armour C \& Woolcock AJ (1998) Effect of dietary intake of omege- 3 and omega- 6 fatty acids on severity of asthma in children. European Respiratory Journal 11, 361365.

Huang C-J, Cheung N-S \& Lu V-R (1988) Effects of deteriorated frying oil and dietary protein levels on liver microsomal enzymes in rats. Journal of American Oil Chemists' Society $\mathbf{6 5}$, 1796-1803.

Ishizaka K (1989) Regulation of immunoglobulin E biosynthesis. Advances in Immunology 47, 1-44.

Kimber I (1998) Allergy, asthma and the environment: an introduction. Toxicology Letters 102, 301-306.

Lai C-C \& Lin B-F (1997) The effects of deteriorated frying oil on the lipid metabolism in BALB/c mice. Nutritional Sciences Journal 22, 33-46.

Lai C-C, Lin B-F \& Lin KW (1997) Effect of high dietary fat and deteriorated frying oil on prostaglandin E2 production in BALB/c mice. Journal of the Chinese Agricultural Chemical Society 35, 401-412.

Lee M-H, Wang M-L \& Min B-W (1990) Effects of methylation on determination of fatty acids. Food Science 17, 1-10.

Lee Y-L, Fu C-L, Ye Y-L \& Chiang B-L (1999) Administration of IL-12 prevents mite Der p1 allergen-IgE antibody production and eosinophils infiltration in animal model of airway inflammation. Scandinavian Journal of Immunology 49, 229236.

Lin B-F, Huang C-C, Chiang B-L \& Jeng S-J (1996) Dietary fat influences Ia antigen expression, cytokines and prostaglandin $\mathrm{E}_{2}$ production of immune cells in autoimmune-prone NZB $\times$ NZW F1 mice. British Journal of Nutrition 75, 711-722.

Lin B-F, Wu I-R, Chiang B-L, Liu J-F \& Huang C-J (1997) Effects of dietary oxidized frying oil on immune responses of spleen cells in rats. Nutrition Research 17, 729-740.

Liu J-F \& Huang C-J (1995) Tissue $\alpha$-tocopherol retention in male rats is compromised by feeding diets containing oxidized frying oil. Journal of Nutrition 125, 3071-3080.
Marom Z, Shelhamer JH, Bach MK, Morton DR \& Kaliner M (1982) Slow reacting substance, leukotriene $C_{4}$, and $D_{4}$, increase the release of mucus from human airways in vitro. American Review of Respiratory Disease 126, 449-451.

National Research Council (1985) Guide for the Care and Use of Laboratory Animals, publication, no. 85-23 (rev.). Bethesda, MD: National Institutes of Health.

Oarada M, Kurita N, Miyaji M \& Terao K (1991) Depression of phagocytic activity of human polymorphonuclear leukocytes by methyl linoleate hydroperoxides. Journal of Nutrition Science \& Vitaminology 37, 625-628.

Oarada M, Majima T, Miyazawa T, Fujimoto K \& Kaneda T (1989) The effect of dietary autoxidized oils on immunocompetent cells in mice. Biochemica et Biophysica Acta 1012, 156160.

O'Byrne PM \& Manning PJ (1992) Clinical relevance of lipid mediators in asthma. Journal of Asthma 29, 153-163.

Omura J \& Sato R (1964) The carbon monoxide-binding pigment of liver microsome. Journal of Biological Chemistry 239, 2370-2385.

Raz A, Wyche A \& Needleman P (1989) Temporal and pharmacological division of fibroblast cyclooxygenase expression into transcriptional and translation phases. Proceedings of the National Academy of Science, USA 86, 1657-1661.

Romagnani S (1990) Regulation and deregulation of human IgE synthesis. Immunology Today 11, 316-321.

Russi AW, Perruchoud AP, Yerger LD, Stevenson JS, Tabak J, Marchette B \& Abraham WM (1984) Late phase bronchial obstruction following nonimmunologic mast cell degranulation. Journal of Applied Physiology 57, 1182-1188.

Sallee EM (1971) Official and Tentative Methods of the American Oil Chemists' Society, 3rd ed., methods cd 3a-63 and 8-53, Champaign, IL: AOCS.

Santoli D \& Zurier RB (1989) Prostaglandin E precursor fatty acids inhibit human IL-2 production by a prostaglandin Eindependent mechanism. Journal of Immunology 143, 13031309.

Schwartz J (2000) Role of polysaturated fatty acids in lung disease. American Journal of Clinical Nutrition 71, Suppl. 1, 393S-396S.

Smit HA, Grievink L \& Tabak C (1999) Dietary influences on chronic obstructive lung disease and asthma: a review of the epidemiological evidence. Proceedings of the Nutrition Society 58, 309-319.

Sperling RI, Robin J-L, Kylander KA, Lee TH, Lewis RA \& Austen KF (1987) The effects of $n-3$ polyunsaturated fatty acids on the generation of platelet-activating factor-activating by human monocytes. Journal of Immunology 139, 4186-4191.

Weaver CT, Hawrylowicz CM \& Unanue ER (1988) T helper cell subsets require the expression of distinct costimulatory signals by antigen-presenting cells. Proceedings of the National Academy of Science, USA 85, 8181-8185.

Yamaoka KA, Dugas B, Paul-Eugene N, Mencia-Huerta J, Braquet P \& Kolb JB (1994) Leukotriene B4 enhances IL-4induced IgE production from normal human lymphocytes. Cellular Immunology 156, 124-134. 